UDC 372.881.111.22

DOI: 10.52534/msu-pp.7(3).2021.47-54

Olena H. Vasylchenko*

Odessa I.I. Mechnikov National University

65082, 2 Dvorianska Str., Odesa, Ukraine

\title{
Features of the Development of Auditory and Pronunciation Skills in Online German Classes
}

\begin{abstract}
Article's History:
Received: 02.05.2021

Revised: 25.06.2021

Accepted: 20.07.2021

\section{Suggested Citation:}

Vasylchenko, O.H. (2021). Features of the development of auditory and pronunciation skills in online German classes. Scientific Bulletin of Mukachevo State University. Series "Pedagogy and Psychology", 7(3), 47-54.
\end{abstract}

\begin{abstract}
The relevance of the research is determined by the need to find new methods of teaching a foreign language in the context of the transition to an online learning environment, which will contribute to ensuring an appropriate level of development of future specialists' communicative foreign competence. The purpose of the study is to determine the features of the development of students' phonetic competence in online German classes on the example of the pedagogical activity of teachers of the I.I. Mechnikov Odessa National University. The study of the selected problems was carried out in two stages based on logical and system approaches using general scientific methods, including the method of analysis, synthesis, comparison, concretisation, systematisation, and the method of analogies. It was identified that the modern educational space is characterised by the digitalisation of the educational process, as a result of which approaches to teaching a foreign language are changing. The paper considers foreign practices of using multimedia technologies in foreign language classes to form students' auditory and pronunciation skills in online learning. The necessity of changing the conventional methods of teaching an introductory phonetic course in a foreign language according to the requirements of distance learning was substantiated. It was established that the key factor in the development of auditory and pronunciation skills in online German classes is the use of video and audio materials (video conferences and messengers), animated images of articulation of sounds, as well as a system of exercises for the practical application of the theoretical knowledge obtained. On the example of teaching an introductory phonetic course in German for first-year students of the Department of International Relations of the I.I. Mechnikov Odessa National University, the basic principles of using mobile applications in the process of distance learning, including Padlet, LearningApps, Voki, PicVoice, and ChatterPix are described. The prospects for further research lie in the practice of using the online environment of an introductory German phonetic course among students of related specialisations
\end{abstract}

Keywords: communication competence, phonetics, distance learning, multimedia platforms, mobile applications

\section{INTRODUCTION}

The process of informatisation of society has an impact on all spheres of life, including education, where these changes are of particular importance. New information technologies are an incentive for the creation of modern methods used in the educational process, the need to switch it into an online environment is dictated by the new challenges of modernity. In the conditions of distance learning, there is a need to revise approaches to the presentation of the material, change the lesson scenario, the need to select suitable online tools (training platforms, mobile applications) so that the quality of learning was not lost, and the motivation of students to study the subject remained high. Access to information and knowledge does not depend on time and location and thus changes the ways of learning.

The relevance of the topic under study is that in Ukrainian and foreign publications, the digitalisation of 
the educational process is considered as one of the decisive factors for the competent organisation of teaching a particular subject. There is a process that connects the analog and virtual world more and more. Combining various means of communication in a smartphone contributes to the increasing connectedness of people with each other. In the context of education, there is a chance to stimulate the autonomy of learning, taking into account the student's abilities and the pace of learning new material [1]. Online tools are used to supplement, and in the forced online phase, replace classroom studies. In both cases, students should be connected with each other, materials should be available after the lesson, the results of the work can be finalised, and the learning process is characterised by transparency and consistency [2].

The use of multimedia technologies in the process of online learning of a foreign language allows not only facilitating the process itself but also expanding student audience. The use of multimedia as a set of means for teaching a foreign language is becoming increasingly relevant both in the training of language specialists and in non-linguistic universities. Competent and comprehensive use of multimedia tools has a positive effect on the process of online learning of a foreign language, contributes to the effective development of lexical, grammatical, and auditory and pronunciation skills.

Special attention should be paid to the development of auditory and pronunciation skills in the process of online learning of a foreign language. The chosen problem has repeatedly become the subject of research by both Ukrainian and foreign researchers. For example, the Spanish scientist M.T. Diez in his research describes the experience of online teaching of French at the State University of Leon [3]. According to the scientist, the best way to develop students' hearing and pronunciation skills is using such online recorders as Jamglue, Podomatic, Twaud.io, AudioBoom, Soundcloud, as well as recording programmes on the computer, including Windows Sound Recorder, StepVoice, Recorder, and Freecorder. At the same time, the University of Leon uses webcams to create videos on the UStream.TV, as well as blogs and podcasts [3]. Such an interactive approach motivates and promotes the development of a receptive and productive pronunciation skill. In addition, a feature of online foreign language teaching at a Spanish university is the use of the social network Ning (Echanges Campus FLE Education) and the audio-visual database Projet Oral FLE Prononciation of the Leon higher educational institution, which contributed to the implementation of oral tasks [3]. Of particular interest are the results of the study of O.Yu. Digtyar [4]. According to the author, online learning of foreign language pronunciation is possible only through teleconferences [4]. At the same time, the learning process itself consists of two stages, which provide for theoretical mastery of the material, as well as practical in the form of training exercises [4]. Researcher K.I. Latyishev believes that the distance course of foreign language phonetics can only be an addition to the main course of study and should provide both correctional and accompanying training [5].

As for the development of auditory and pronunciation skills among students on the example of German online classes, it is worth noting that according to a study conducted at the Goethe-Institut, the use of multimedia tools, mobile devices, and applications using which learning can take place in various contexts, both formal and informal, has proven to be a good side of distant language learning [6]. Obviously, when planning a student-centred lesson, the needs of students should be taken into account first of all. In both cases, students are motivated to learn new things and solve problem situations, which corresponds to the main purpose of teaching foreign languages, namely, the development of foreign language activity-based communicative competence. In addition to motivation, an important role in the organisation of online learning is played by the relevance and attractiveness of the offered educational materials, as well as the professional and business competence of the teacher. The interest of students at the initial stage is usually very high, and the teacher faces the task of supporting it, which is facilitated by the use of modern methods and training platforms that stimulate interaction between participants of the educational process. Regardless, the problem of the development of communicative and phonetic competencies in online classes remains poorly studied, and therefore the purpose of the paper is to determine the features of the development of auditory and pronunciation skills in students of German classes on the example of the experience of the I.I. Mechnikov Odessa National University.

\section{MATERIALS AND METHODS}

The study of the development of auditory and pronunciation skills in online German classes was conducted in two stages. The first stage involved the analysis of scientific and methodological literature in the context of online teaching of a foreign language, in particular with an emphasis on the development of phonetic competence. The second stage of the study is focused on identifying the features of the development of auditory and pronunciation skills in online German classes on the example of the experience of the I.I. Mechnikov Odessa National University.

To achieve this purpose, the author used such general scientific research methods as analysis, synthesis, comparison, concretisation, the method of analogies, and systematisation. Thus, the analysis method was used to process scientific and journalistic literature on the topics of online foreign language teaching, as well as the use of modern multimedia technologies and mobile applications for educational purposes. The synthesis method helped considering the data together, in particular, brief information about the research results of other scientists obtained in the analysis of scientific and journalistic literature. The comparison method was used to correlate the functioning of the introductory phonetic course, and, accordingly, the development of auditory 
and pronunciation skills in students in the conditions of offline and online learning of German. The method of concretisation was used to study the features of the development of auditory and pronunciation skills in online German classes in the context of the functioning of the introductory phonetic course in German for first-year students of the Department of International Relations of the I.I. Mechnikov Odessa National University. At the same time, the analogy method made it possible to compare the functional features of multimedia platforms and mobile applications, such as Padlet, LearningApps, Voki, PicVoice, and ChatterPix. The method of systematisation helped to display the stages of studying phonetic material in accordance with the principle of gradual increase of difficulties, ways of implementing the principle of clarity in online classes, as well as elements of online classes in German.

As a theoretical basis, scientific and journalistic works of Ukrainian and foreign scientists were used, as well as laws and regulations of the international level, which contributed to the study of views on the control of the development and improvement of auditory and pronunciation skills in students. In general, the study is based on logical and system approaches. Thus, due to the logical approach, phonetic competence, in particular auditory and pronunciation skills, was considered as an object of research in accordance with the principle of comprehensiveness and sufficient justification. The system approach made it possible to consider the development of auditory and pronunciation skills in students as the development of theoretical and practical skills and abilities in their integrity and interrelation.

\section{RESULTS AND DISCUSSION}

\section{Introductory phonetic course in German in offline and online environment: Features of teaching}

Usually, teaching a foreign language begins with an introductory phonetic course. As a rule, according to N.A. Kindrya, "the introductory phonetic course is a specialised curriculum that relies on both the native language and interlanguage" [7]. The researcher believes that the introductory phonetic course is based on the analysis of the phonetic features of the native and foreign languages, which contributes to the identification of language interferences and, accordingly, the search for methods to solve them [7]. Therefore, the introductory phonetic course is mandatory for students who are beginning to learn German as a primary and second foreign language. Along with the development of auditory and pronunciation skills, the development of linguistic, sociocultural and intercultural, pragmatic and communicative competencies takes place within the framework of the introductory phonetic course. The main purpose of the course is to form students' auditory and pronunciation skills that are as close as possible to the development of pronunciation with no accent and to create a solid foundation for further work on improving the sounding speech, which is the leading component of communicative competence. For example, the introductory phonetic course in German for students of the I.I. Mechnikov Odessa National University contains a large number of exercises, where the most important distinctive features in the studied and native languages are taken into account, recommendations are given to prevent typical errors that arise as a result of the interfering influence of the Russian and Ukrainian languages. The course is based on the Deutsch akzentfrei [8] textbook, has a lesson structure and consists of 12 lessons, each of them has different social work forms (front, independent, group, and plenary) at the offline lesson, and phonetic exercises compiled with strict regard to the gradual introduction of phonetic material according to which the new phoneme or intonation model do not occur in any of the previous exercises prior to their introduction. Thus, a rational sequence of studying phonetic material is carried out according to the principle of gradualness in the increase of difficulty. The exercises are presented in the following order (Fig. 1):
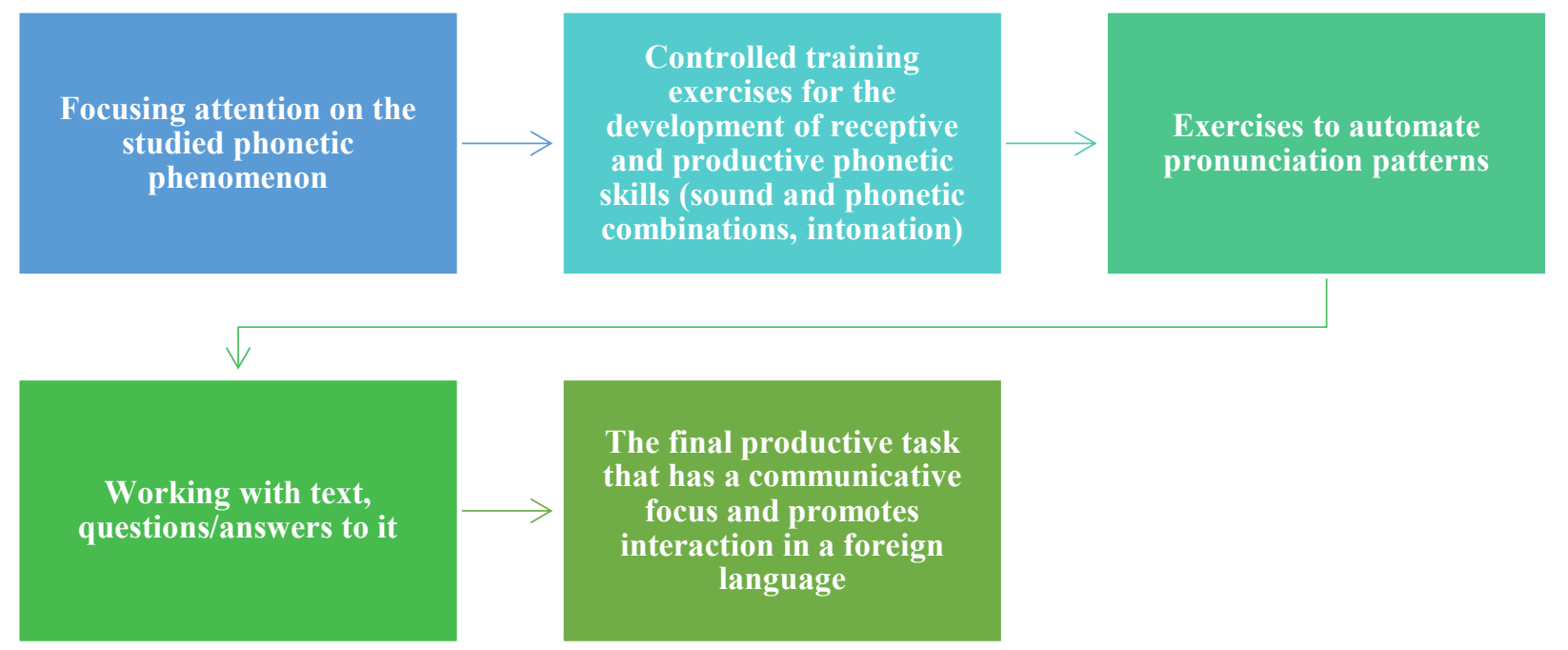

Figure 1. The scheme of studying phonetic material according to the principle of gradualness in the increase of difficulty 
As can be seen from Figure 1, the language material of the texts, as well as visual and auditory visibility, situational conditionality of tasks allows from the very beginning of training to perform not only linguistic (training, preparatory) but also speech (conditional-communicative and communicative) exercises that contribute to the development of discursive competence. At the same time, the new challenges of modernity, namely the need to switch the introductory phonetic course to an online format in the conditions of distance learning, requires a revision of such a conventional approach to the presentation of the material and a change in the scenario of classes. There is a need to select suitable online tools for organising distance learning (training platforms, mobile applications), provided that the high level of quality of training and students' motivation is maintained. The teacher needs to build a new system of motivation and support for students, provide regular feedback from his side, think over and organise assessment methods using modern multimedia tools. At the same time, the main purpose of learning a foreign language - the development of foreign language communicative competence should not be affected.

It is also worth noting that the online development of foreign language communicative competence depends on the conditions of computer-mediated communication, which qualitatively changes the interaction between the student and the teacher. Therefore, this contributes to additional research within the framework of the concept of social presence, which is a subsection of communication theory, as well as to the search for a link between social presence and the development of students' cognitive understanding of the learning content, their motivation and critical thinking [9]. For example, according to D. Zolotukhin, the use of computer-mediated learning offers a transition from the conventional position of the teacher "the sage on the stage" to the position of "guidance from the outside" [10]. In this case, the key aspects of social presence are communication and interaction. It is these two aspects that must be taken into account both in classroom studies and in online classes, in synchronous (video conferences) and asynchronous (training platforms, mobile applications) formats. Modern multimedia platforms are able to provide interactive learning, which should not, however, be confused with interaction, which manifests itself in the communication of students among each other and with the teacher. The modern theory of online learning recognises the importance of interaction between the student and the teacher. This interaction can be manifested in the form of informal messages by e-mail, in chats, forums, comments, in other words, in the presence of feedback, especially in the conditions of distance learning. Timely feedback from the teacher creates a so-called social presence and has a positive impact on the assimilation of the material by students, helps in maintaining the pace of learning and provides a positive atmosphere.

In the conditions of modern communication and forced online phase, multimedia platforms for online learning perfectly cope with the organisation of a continuous educational process. However, in reality, many teachers are faced with the lack of such universal platforms for distance learning in their educational institutions. In such cases, one of the simplest, affordable, and at the same time effective ways turned out to be the use of messengers (Viber, Telegram, WhatsApp), live video conferencing services (Zoom, Skype, Google Meet), and mobile applications (Quizlet, Quizizz, Kahoot!, Padlet, PicVoice, and many others). These tools made it possible to successfully provide training in synchronous (video conference format) and asynchronous (messengers, mobile applications) formats, including as part of an introductory phonetic course in German for first-year students of the Department of International Relations of the I.I. Mechnikov Odessa National University, the specifics of which is that both the teacher and the students work with the sounding speech. Thus, due to the live video conferences format, although within a limited time, it was possible to hear the teacher, see their articulation, repeat the material, and immediately receive feedback. However, it is impossible to exclude the poor quality of the Internet connection, which affects the sound signal and the picture. An important condition for the successful achievement of the purpose of the introductory phonetic course and the development of stable auditory and pronunciation skills is the students' ability to turn to the sounding samples at any time on the one hand, to hear themselves on the other hand, and, of course, to get feedback from the teacher. Messengers (Viber, Telegram, WhatsApp) and a voice recorder on mobile devices played a special role at the initial stage of adaptation of teachers and students to the new format, which made it possible to receive audio files of sounding samples from the teacher, record themselves and send the completed exercises in audio format to the teacher, receiving appropriate recommendations in response. Video conferences and messengers, in fact, ensured the continuity of the learning process, taking into account the features of the introductory phonetic course: the first step was to work in a class held in the video conference format (synchronous work), the second step provided the sounding samples, the opportunity to record themselves, hear from the outside, analyse errors, get feedback from the teacher (asynchronous work in messengers). Independent and responsible work of students plays a crucial role in the second step, which ensures the continuity of learning and the development of the necessary auditory and pronunciation skills.

In the context of online communication, in addition to video conferences and audio materials, it is worth paying attention to one of the main methodological conditions for the development of students' phonetic speech skills, namely, the presence of animated images of articulation, which, when teaching foreign pronunciation, are the implementation of the didactic principle of clarity. In the "Essays on the psychology of teaching foreign languages", B.V. Beliaev argued that "the principle of visibility should be considered not as an auxiliary, but as one of the main methodological principles of teaching a foreign language when this training pursues practical purposes" [11]. In online learning, this principle can be implemented in several ways (Fig. 2): 

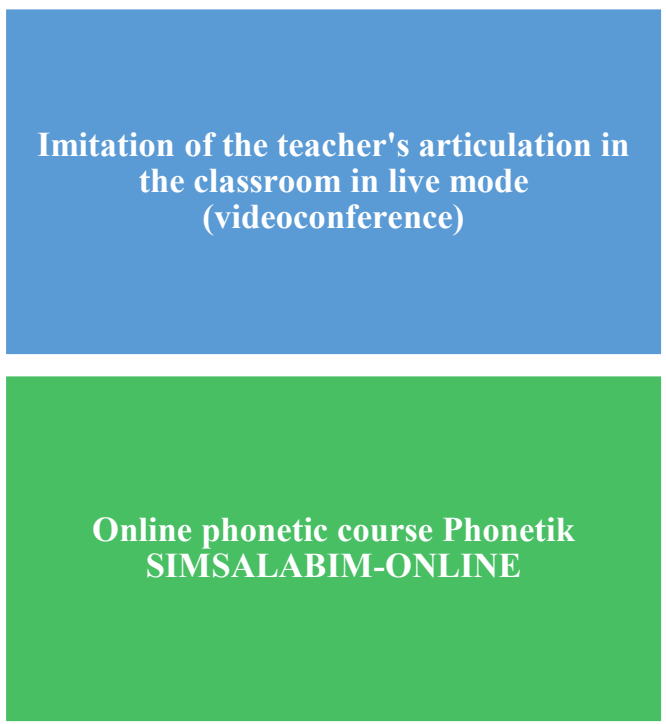
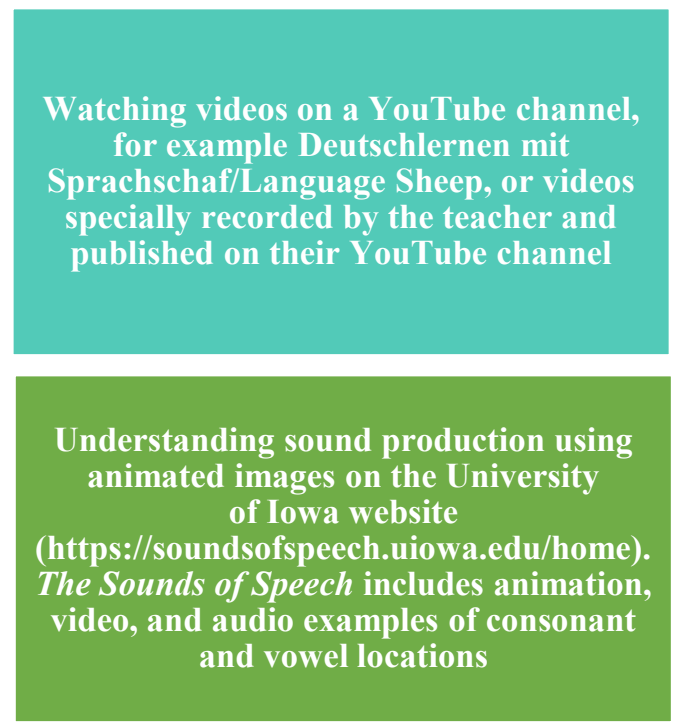

Figure 2. Ways of implementing the principle of visibility in online classes

As is evident, the animation material serves as an external support and an example of articulation of foreign sounds, helps students to better understand and realise how each specific sound is pronounced. The lack of animated images of articulation complicates the process of developing sound-pronouncing skills.

\section{Transfer of practical exercises of the introductory phonetic course into an online format and methods of monitoring their implementation}

The methodological condition for the development of students' phonetic speech skills is the presence of a series and cycles of training exercises for the development of sound-pronouncing and rhythmic-intonational skills and is one of the most difficult issues that require comprehensive exercise. The necessary set of exercises, which previously proved itself well in the conditions of offline training, is presented in the textbook of the introductory phonetic course
Deutsch akzentfrei [8]. To effectively solve this issue in the conditions of online learning, it is necessary to remember about the combination of three elements of online classes, which must be considered as a whole (Fig. 3).

Figure 3 demonstrates that the first element (Pre-class activities) is an input phase, the second (Live class) is characterised by cooperative work and communicative orientation (Collaboration and Inter-action, for example, group work in breakout rooms in Zoom), and third (Post-class activities) is an independent consolidation. If the second element is a direct communication between a student and a teacher, as well as students among each other in a synchronous video conference format, then for the implementation of the first and third elements, it is assumed that available mobile applications are used to ensure the continuity of learning, support motivation to learn a foreign language, and stimulate independent work of students.

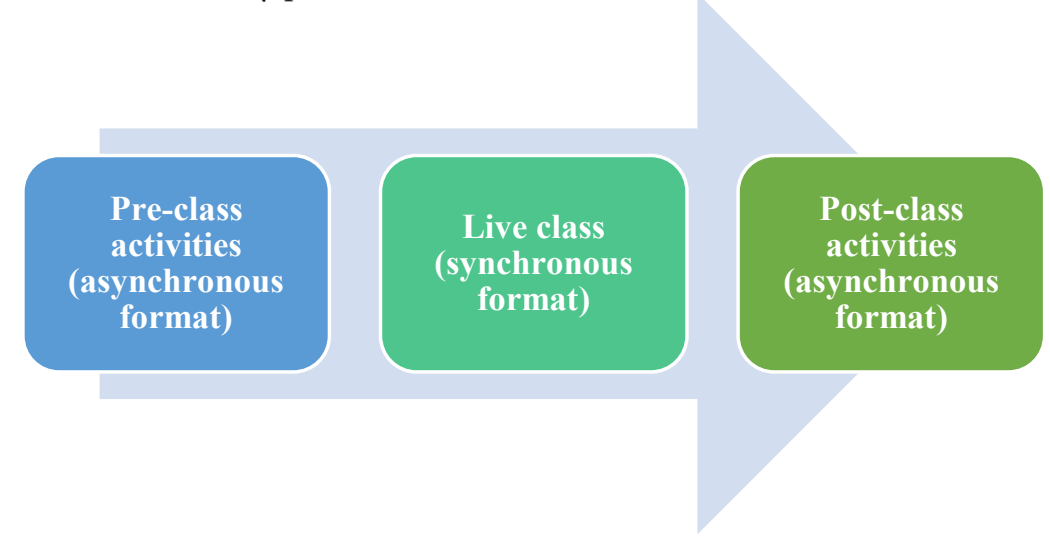

Figure 3. Key elements of online German language classes

Moreover, work in an asynchronous format is characterised by accessibility, ease of use, and receiving automatic feedback about the results of the completed task. The author's research is based on an introductory phonetic course in German for first-year students of the Department of International Relations of the I.I. Mechnikov Odessa National University in the conditions of online learning, which provided for the use of such mobile applications as Padlet, LearningApps, Voki, PicVoice, and ChatterPix. Thus, the Padlet online service was actively used by students 
for independent work in the phases of asynchronous learning since the application has the ability to download audio and video files, images, as well as active links. In addition, the Padlet application is useful for the development of auditory and pronunciation skills of foreign language:

1.To focus attention on the studied phonetic phenomenon, the teacher uploads the necessary audio material to the platform (for example, training exercises), as well as, if necessary, active links (for example, to The Sounds of Speech of the University of Iowa), access to which is unlimited for students.

2. Students, working independently, bring pronunciation samples to automation, record them in an audio format, and upload them to the platform. Thus, both the teacher and students have the opportunity to listen to audio recordings and give feedback (for example, in the form of a comment).

3. Padlet is also suitable for performing a final productive task that has a communicative orientation and completes each lesson of the Deutsch akzentfrei textbook [8], and also allows organising collegial feedback, which meets modern methodological requirements.

In addition to the Padlet online service, students used the LearningApps application, which contributes to the creation of interactive exercises for listening and recognition of rhythmic-intonational patterns. For its part, the online service Voki allows creating talking interactive avatars. As part of the introductory phonetic course, this is a great opportunity to train sounding speech (both monological and dialogical), send audio recordings and receive the necessary feedback. It is worth noting that to improve the skills of sounding speech, the mobile applications PicVoice and ChatterPix have proven themselves perfectly, with their help one can voice any image (photo or picture). For example, as a productive task for completing an introductory phonetic course in an online format at the I.I. Mechnikov Odessa National University, first-year students of the Department of International Relations were offered to use the PicVoice application and the Padlet online service. Students were choosing one of the figures accompanying each lesson from the textbook Deutsch akzentfrei [8], and using PicVoice described the situation depicted in the figure, demonstrating the level of completeness of the pronunciation skill. The completed interactive tasks were placed on the Padlet interactive board with the opportunity for all participants of the educational process to listen to the created product, leave a comment, or ask a question. The teacher had the opportunity to evaluate the results of the work and give feedback.

Thus, from the very beginning of training, students perform not only linguistic (training, preparatory) but also speech (conditional-communicative and communicative) exercises, which eventually contribute to the development of discursive competence. Using mobile applications and Internet resources, the teacher independently creates a gamified motivating virtual learning environment with a sequencing of three types of exercises (Fig. 4):
Training exercises that do not repeat the verbal and

cogitative actions of real communication, but aimed at working out and consolidating the linguistic (in the case of the study of phonetic) material
Conditional communication exercises that imitate and simulate a communicative situation for educational purposes
Genuine communicative tasks,

during which students completely repeat speech and cogitative functions and use a foreign language in authentic situations, as in real communication

Figure 4. Classification of exercises in a virtual learning environment

In conclusion, it should be noted that multimedia platforms, live video conferences, as well as mobile applications, contribute to high-quality online teaching of the German language, in particular the introductory phonetic course, but in the conditions of distance learning the question arises about the methods of monitoring the implementation and development of the necessary competencies. Both in the classroom and in the online learning, the teacher exercises current and final control over the performance of tasks by students, based on the criteria and indicators of the level of completeness of auditory and pronunciation skills.
The Begleitband zum GeR/Common European Framework of Reference for Languages, published in 2018, presents a completely revised phonological competence assessment scale, as well as new scales for assessing segmental and suprasegmental competencies [12]. It is necessary to take into account that the assessment of pronunciation competence to a much greater extent compared to other areas of the language (for example, grammatical) depends on the preliminary knowledge and skills of the evaluated students. While incorrect grammatical constructions are easy to identify, there are no unambiguous criteria for evaluating 


\section{CONCLUSIONS}

"good pronunciation". Previously, when evaluating, the focus of attention was on the absence or presence of a foreign language accent: "The phonology scale was the only CEFR illustrative descriptor scale for which a native speaker norm, albeit implicit, had been adopted" [13]. Since in the modern methodology of foreign language teaching the main objective is the development of communicative competence, the assessment of student's phonological competence according to the updated criteria focuses on whether his pronunciation is clear enough not to disrupt the communication process: "Students whose L2 production is not entirely native-like but who are able to communicate effectively are successful L2 users" [14]. All training exercises and final productive tasks adapted for working in the online mode have a communicative orientation and contribute to interaction in a foreign language within the framework of acquired auditory and pronunciation patterns. The process of automating auditory and pronunciation skills can be considered complete only when the student can use the material in natural acts of communication, which is the main indicator of the level of completeness of auditory and pronunciation skills.

In general, it should be noted that the optimisation of the educational process in an online format using information and computer technologies plays an extremely important role in improving student-teacher communication and promotes active learning of a foreign language, in particular, mastering phonetic competence [15].
Thus, on the example of the experience of conducting an introductory phonetic course for first-year students of the Department of International Relations of the I.I. Mechnikov Odessa National University, the features of the development of auditory anf pronunciation skills in online German classes were considered. Summarising the above, it can be concluded that due to such characteristics as interactivity, autonomy, versatility, and accessibility, online resources and mobile applications have great potential in teaching foreign languages, in particular in the framework of teaching auditory and pronunciation skills. These tools create conditions for the development of students' ability to self-development and self-education, increase students' responsibility for their learning and motivation for learning activities, create psychologically comfortable conditions for the development of such types of speech activity as listening and speaking, promote the development of auditory and pronunciation skills, ensure the continuity of the process of learning a foreign language in the conditions of forced online learning, and also develop students' creative abilities. In the author's opinion, however, a necessary condition for effective online learning is, firstly, free access for teachers to online resources including multimedia Internet platforms (for example, Moodle), using which it is possible to comprehensively plan distance learning, including an introductory phonetic course, and secondly, increasing media literacy of both students and teachers.

\section{REFERENCES}

[1] Honegger, B.D. (2016). More than 0 and 1 (1st ed.). Bern: hep Verlag.

[2] Brash, B., \& Pfeil, A. (2017). DLL 09: Teaching with digital media. München: Goethe-Institute.

[3] Diez, M.T. (2020). Online techniques for correcting the pronunciation of learners of French as foreign language. Theleme, 35(1), 85-93.

[4] Digtyar, O.Yu. (2019). The problems of distance learning education while teaching foreign languages at a non-linguistic higher school. World of Science, Culture, Education, 1(74), 356-357.

[5] Latyishev, K.I. (2020). Distance accompanying course of English phonetics within the framework of the Zoom videoconferencing program: A special course for students of non-philological specialties: The main stage of training. Sci-Article, 87. Retrieved from https://sci-article.ru/stat.php?i=1601994990.

[6] Iberer, U., Wipperman, S., \& Muller, U. (2014). From innovation project to established blended learning. In C. Spary (Ed.), E-learning: Education 2.0? Requirements on the electronic way of individualized learning environments (pp. 76-98). Berlin: RabenStück.

[7] Kindrya, N.A. (2015). Teaching an introductory phonetic course, taking into account the peculiarities of the Russian language and individualization. Young Scientist, 22(102), 805-808.

[8] Verbytska, T.D., \& Hryshyna, T.V. (2014). German without accent. Odesa: Astroprint.

[9] Richardson, D.C., Spivey, M.J., McRae, K., \& Barsalou, L.W. (2003). Spatial representations activated during real-time comprehension of verbs. Cognitive Science, 27, 767-780.

[10] Zolotukhin, D.S. (2018). Term, object and point of view in linguistics: the specifics of interaction. In Current issues of linguistics and linguodidactics: Traditions and innovations: materials of the scientific conference with international participation (pp. 33-40). Moscow: MPSU.

[11] Beliaev, B.V. (1965). Essays on the psychology of teaching foreign languages (2nd ed.). Moscow: Prosveshchenie.

[12] The new companion volume to the Common European Framework of Reference. (2020). Retrieved from https://www.klett-sprachen.de/referenzrahmen/c-3074.

[13] Common European framework of reference for language. (2020). Retrieved from https:/www.coe.int/en/web/ common-european-framework-reference-languages.

[14] Kennedy, S., \& Trofimovich, P. (2008). Intelligibility, comprehensibility, and accentedness of L2 speech: The role of listener experience and semantic context. The Canadian Modern Language Review, 64(3), 459-489.

[15] Liu, M., \& Yu, J. (2022). Model optimization of computer-aided English teaching in local area networks. Computer-Aided Design and Applications, 19(S1), 128-138. 


\title{
Олена Германівна Васильченко
}

Одеський національний університет імені I.I. Мечникова

65082, вул. Дворянська, 2, м. Одеса, Україна

\section{Особливості формування слухо-вимовних навичок на онлайн-заняттях з німецької мови}

\begin{abstract}
Анотація. Актуальність дослідження визначається потребою в пошуку нових методів викладання іноземної мови в умовах переходу на онлайн-формат навчання, що сприятиме забезпеченню належного рівня розвитку комунікативної іноземної компетентності майбутніх фахівців. Метою роботи є визначення особливостей формування фонетичної компетенції студентів на онлайн-заняттях з німецької мови на прикладі педагогічної діяльності викладачів Одеського національного університету імені I.I. Мечникова. Дослідження обраної проблематики проводилося в два етапи на основі логічного тасистемногопідходів з використанням загальнонаукових методів, серед яких метод аналізу, синтезу, порівняння, конкретизації, систематизації та метод аналогій. Виявлено, що сучасний освітній простір характеризується діджиталізацією навчального процесу, внаслідок чого змінюються підходи до викладання іноземної мови. У роботі розглянуто зарубіжні практики використання мультимедійних технологій на заняттях з іноземної мови з метою формування слухо-вимовних навичок у студентів в умовах онлайн-навчання. Обгрунтовано необхідність зміни традиційних методів викладання вводно-фонетичного курсу з іноземної мови відповідно до вимог дистанційного навчання. З’ясовано, що ключовим чинником формування слухо-вимовних навичок на онлайн-заняттях 3 німецької мови $€$ використання відео- та аудіоматеріалів (відеоконференції та месенджери), анімаційних образів артикуляції звуків, а також системи вправ 3 метою практичного застосування набутих теоретичних знань. На прикладі викладання вводно-фонетичного курсу 3 німецької мови для студентів першого курсу відділення міжнародних відносин Одеського національного університету імені I.I. Мечникова описано основні принципи застосування мобільних додатків у процесі дистанційного навчання, серед яких Padlet, LearningApps, Voki, PicVoice та ChatterPix. Перспективи подальших досліджень полягають у практиках застосування онлайн-формату вводно-фонетичного курсу з німецької мови серед студентів суміжних спеціальностей
\end{abstract}

Ключові слова: комунікативна компетентність, фонетика, дистанційне навчання, мультимедійні платформи, мобільні застосунки 